\title{
島津藩政時代の茶の歴史 (III)
}

静岡県茶生産農業協同組合連合会 足 立 東 平

\section{- The History of Tea in Shimazu Era (Part 3)}

\author{
By Tôhei ADACHI
}

\section{6 茶に関して古くから世に伝わる 物件（補遺）}

\section{1 茶碗}

(1) 由緒ある茶碗

(a) 忠良公 (日新公) 御使用のお茶碗

大浦 (川辺郡笠沙町) の吉見敦男氏が所蔵されている もの。牡丹に唐草がえがかれた煎茶茶碗で, その形や模 様などからすると，渡来品のように思われる。（本誌 No. 8, p. 122, 写真 14 参照)。吉見氏の宅には, 今でも 庭前に日新公のほこらが設けられているが，その昔、日 新公のお宿をつとめた家がらである由。

(b) 義弘公御使用の金の茶碗

既報 (本誌 No. 8, p. 122 参照)。

(c) 桃園天皇御下賜の宕碗

池田貞記は茶一壶を桃園天皇に献上してえい慮をこう むり, 菊花御紋章付き茗碗, その他色紙, たんざくなど を賜わった。(本誌 No. 8, p. 118, 119 参照) この若 碗は貞記の 6 世にあたる都城市池田䒴男氏 (神戸市在住) の所有となっており, 現物は宮崎市神武宮庭徵古館に陳 列されている（延岡市四倉宴城氏のたよりによる）。

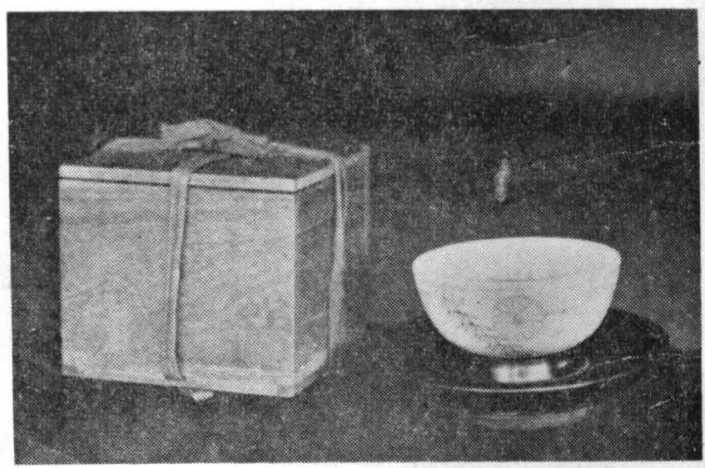

写真 15 桃園天皇御下晹の茗碗 （都城市 池田芳男氏蔵）

(d) 高 震 茶 碗

慶長年間 (1596〜) 沈家の祖先が, 朝鮮から师化せら れたおり，たずさえてきた得がたい宝器，います沈寿官 氏が秘蔵されている。この茶碗は一説には, 火計茶碗 (後出) とも言われている。沈寿官は帰化以来代々襲名
して, 苗代川焼き(鹿児島県日置郡伊集院町) のかまを 今日まで連綿と続けてきている。

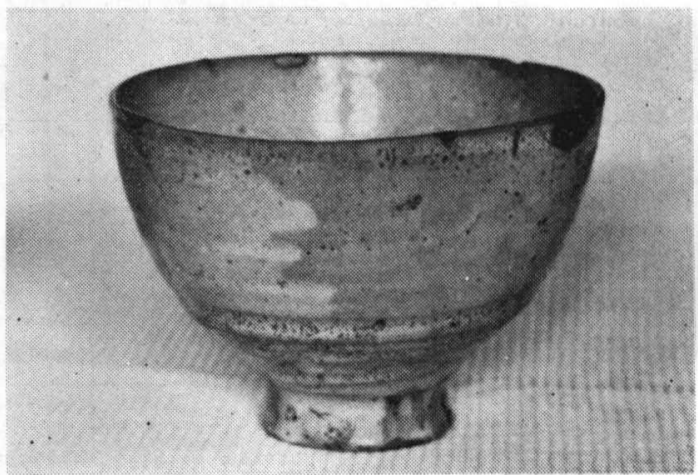

写真 16 高 麗 茶 碗

（鹿児島県伊集院町 沈寿官氏蔵）

(2) 藩主お手作りの茶碗

(a) 義弘公お手作り茶碗

義弘公お手作り茶碗は非常に珍しく，かつまたたいい んに貴重である。写真17 は義弘公お手作りと伝えられる 茶碗で，黒みがふったかっ色のまことに渋味のあるはだ 色, 茶碗の裏底に「慶長八 義弘作之」の刻銘がはいっ ている。

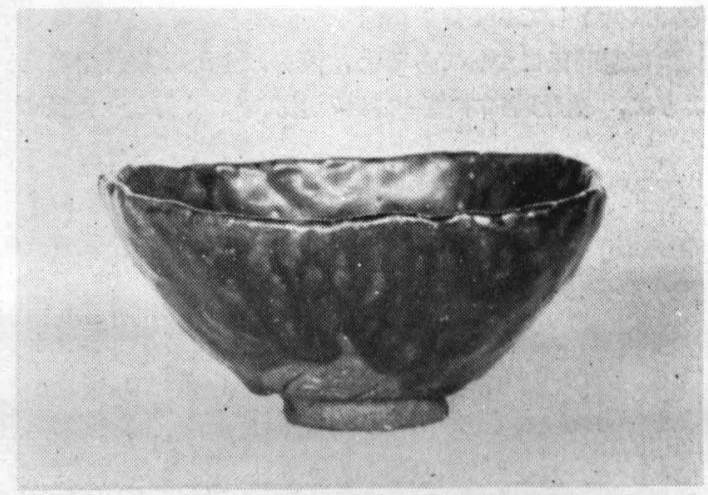

写真 17 義弘公お手作り茶碗 （鹿児島市 中尾健次氏藏）

(b) 斉樹公お手作り茶碗

斉楖公お手作りのまっ茶茶碗のうちで, 特に興味をそ そるのは, 嘉永巳西11月11日, 河村某に拝領仰せ付けら 
れた旨箱書きされた，斉森公お手作りの筒茶碗“ボン ペン”である(写真18)。公は写真にみるように, 臼砲 の形に模して茶碗を作り, これに,

炉にかまに 道具そろえて こと国の

ふねをみじんに うてやボンベン

という和歌を焼きだして，近親や家臣に配与世られたと いう。当時臼砲のことを“ボンベン”を称えられてい た。幕末の風雲急であったととが，身近に感じさせられ る。

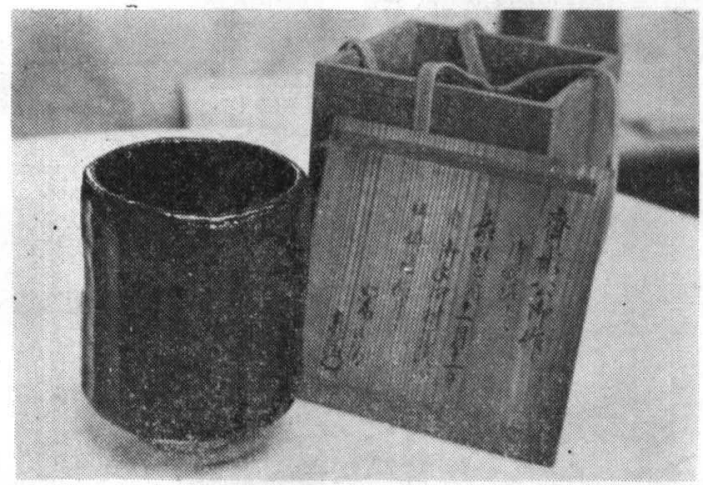

军真 18 斉樹公扮手作り筒茶碗“ボンベン”

直径 $10.9 \mathrm{~cm}$, 高さ $14.2 \mathrm{~cm}$

（鹿児島市 尚古集成館陳列）

（c）忠義公抒手作り茶碗

写真19 は抢庭焼きの 1 種で, 土の種類やはだ色などか らすると，しろうと目には長太郎焼きによく似かよって 見える。向かって左滄青みがかった濃いグレーで, 強い つやがある。右は赤みがかったチョコレート色で，つや のない渋いはだ色。二つとも茶碗の裏底に, 桜の花の刻 印がおされている（桜の刻印は島津藩お庭焼きのしる ()。

军真19，20 法忠義公お手作りの茶碗。

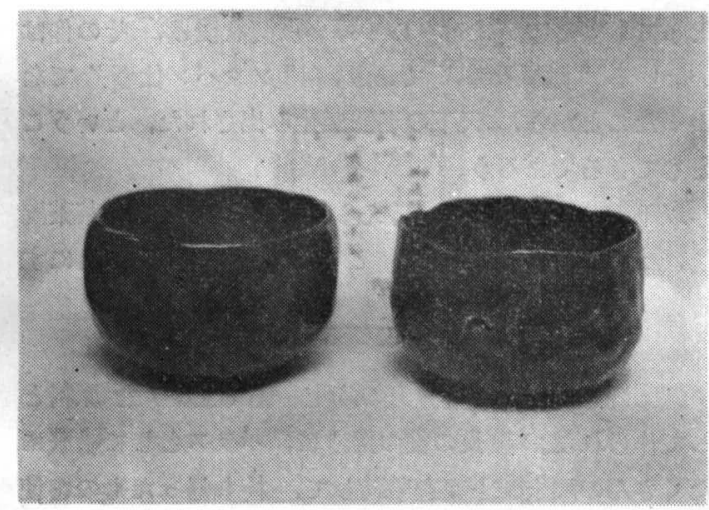

写真 19 忠義公打手作り茶碗 (その1) 向って左 口径 $9.7 \mathrm{~cm}$, 高さ $6.4 \mathrm{~cm}$ 向って右 口径 $9.7 \mathrm{~cm}$, 高さ $6.7 \mathrm{~cm}$ （鹿児島市 尚古集成館陳列）

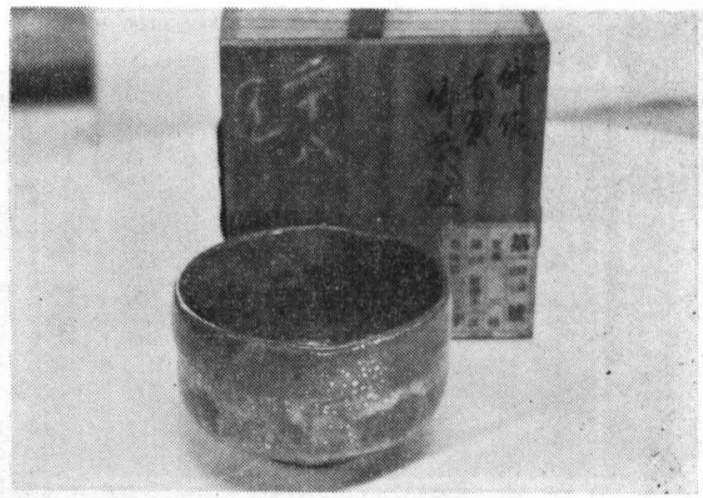

写真 20 忠義公打手作り茶碗 (その 2) 赤楽 茶碗 口径 $11.3 \mathrm{~cm}$, 高さ $7.0 \mathrm{~cm}$ （鹿児島市 尚占集成館陳列）

(3) 御判手茶碗

慶長 6 年 (1601) 関ガ原の役の問題が落着し, 島津家 の領土が一応あんどすると, 義弘公は関ガ原の役の責任 をとり帖佐に隠居して，国務は家久に譲った。そして 市来に上陸した金海 (朝鮮からつれてきた) を帖佐に呼 んで, 宇都にかをを開かせ，また芳忠に命じて分日町に 開窝させた。それから 7 年後の慶長13年 (1608) 義弘公 は加治木に居を移したが，同時に宇都・八日町のかまを 廃して金海・芳忠も同地汇呼んだ。金海は義弘公居城の 北隣りに，芳忠は竜口坂に，それぞれかまを構えた。義 弘公は帖佐・加治木で，またときおり苗代川にもおもむ いて, 好みの茶器を作らせ, ロク口仕上げをすませたば かりの茶器に, みずから「義」の字を刻し, 不できのも のは捨てさせて，気に入ったものばかり炭残した。これ は当時御判手といって, 非常に珍重された。

「加治木古老物語」によると，

帖佐御判手御茶碗, 先年, 鄉原転殿, 御拝見被成 候而, 此茶碗今にしても被下候はば, 指一つ二つ 切候共, ほしき由, 御吐為被成申候。

とある。珍重のほどが察せられる。

義弘公の御判手には, 以上のほかに, 韓・萬などの文 字を刻せしめ，または印形を入れられ，あるいはみずか らぼ印を打されたものなどがある。

御判手茶碗は義弘公以来, 後代の藩主の代にもみられ る。

(a) 義弘公御判手茶碗

写真21 はうすい卵色の無地, 茶碗の内外にヒビレのは いったように見えるのは，金をはめ込んだもので，傷で はない。

写真22 も義弘公の御判手であるが，これには刻印はな く，義弘公の济印が怙されている。その指形が途方むな く大きいのが目立っている。

義弘公の御判手茶碗で, 阿久根市 (鹿児島県) の田野 


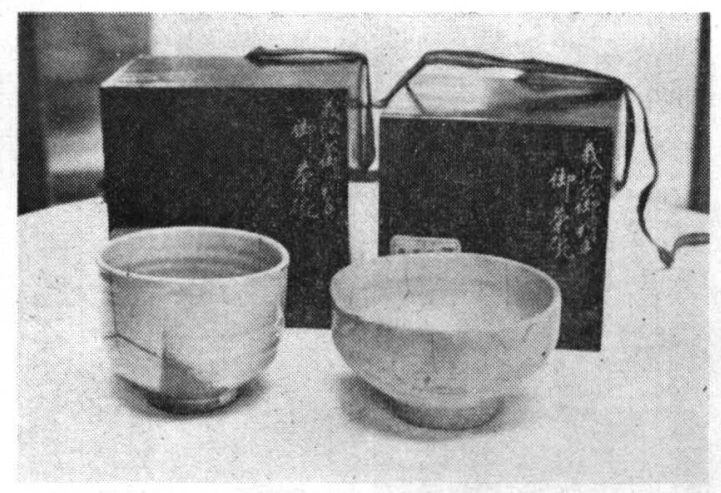

写真 21 義弘公御判手茶碗 (その1) 向かって左 口径 $12 \mathrm{~cm}$, 高さ $9.2 \mathrm{~cm}$ 向かって右口径 $13.5 \mathrm{~cm}$, 高さ $7.3 \mathrm{~cm}$ (鹿児島市 尚古集成館陳列)

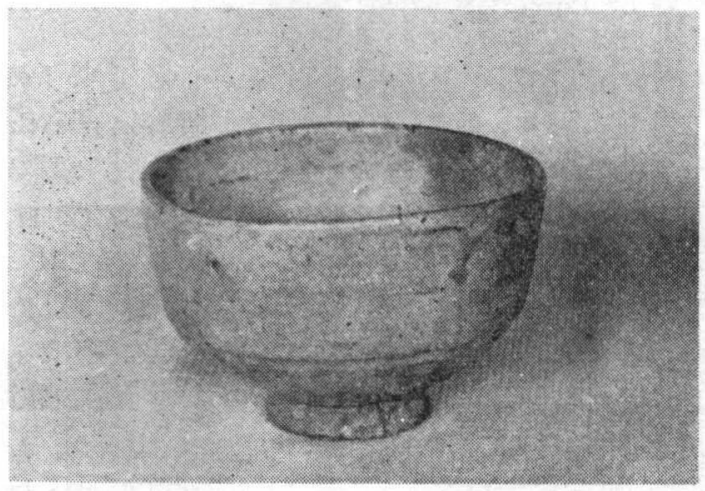

写真 22 義弘公御判手茶碗（その2） （鹿児島市 中尾健次氏蔵）

さん所蔵のものは, そのできが非常によく, 御判手茶碗 のうちの逸品と言われていて，それには御判手を証明す る, 次のような古交書がついている。 義弘公陽明殿勤任の間命に依り印刻 之を識す。

右萬字明らかなり。 近習水竹主馬

(b) 斉森公御判手茶碗

写真23 は牡丹花形茶碗, 箱書に内白薬・外紫薬とある が，内縁の白に対する外回りのうす紫は対照もよいし， はなはだ優雅な感じを与えている。斉须公の御判手に は, このほか黑楽茶碗, 金溜茶碗, 击庭焼き茶碗, 平楽 茶碗など、ここに書き尽くせないほど，さまざまなしか む貴重なまっ茶茶碗が, 今日尚古集成館 (島津家) に保 存されている。

(c) 忠義公御判手茶碗

写真24 は荷葉御茶碗, 千葉蝶絵付と箱書きされた忠義 公の御判手茶碗である。

(4) 薩摩焼茶碗のいるいろ

義弘公以来の薩摩焼きのなかに、, 茶人の間に珍重さ

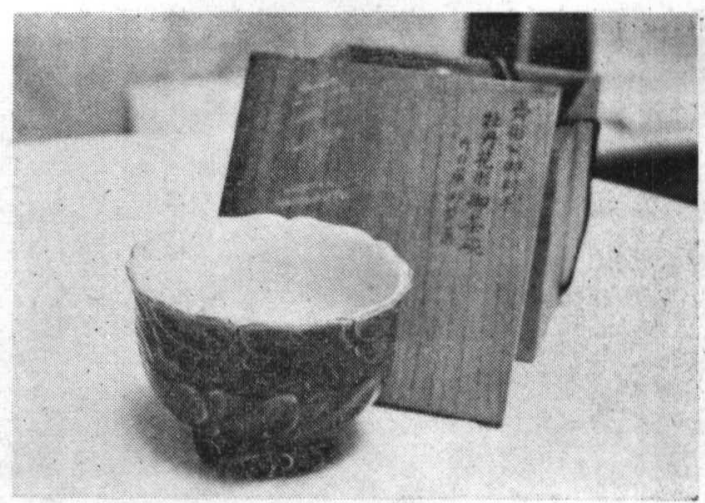

写真23 斉彬公御判手 牡丹花形茶碗

口径 $12 \mathrm{~cm}$, 高さ $8 \mathrm{~cm}$

(鹿児島市 尚古集成館陳列)

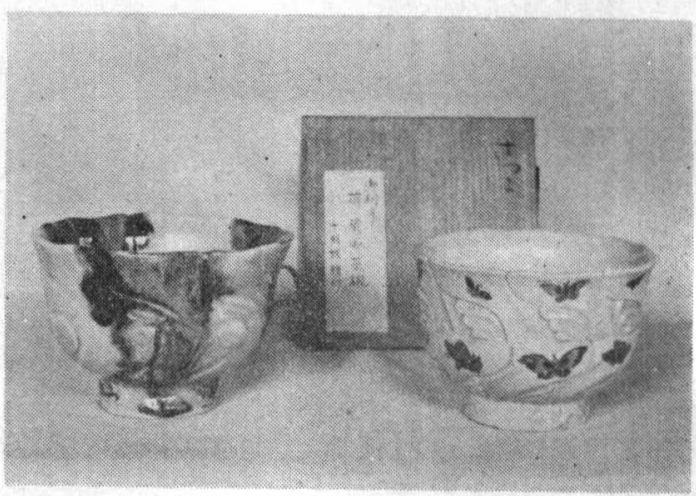

写真 24 忠義公御判手

荷葉茶碗

千葉蝶絵 付

(鹿児島市 中尾健次蔵)

れた名器が、少なからず残り伝えられている。

これらの名器は多くの場合, 有名茶人と名工とが, 同 時に出たときに作られたものといわれる。しかしなな としても当時の陶工は藩の手厚い保護を受け，その作は いわゆる“殿㥞仕事”であり，“ソロバン仕事”でな かったととから, 天下の名器が生み出された, というこ ともできるであろう。

以下藩政時代の作と伝えられる代表的なまっ茶茶碗 を，お拉ねかまの別に，ここに揭げてみるととにす る。

(a) 炎計 茶碗

薩摩焼きは当初朝鮮渡来の陶土・釉 ( して作られた。慶長の役の帰りに, バラスとして船底に たくさんの陶土・上薬を積荷して, 持ら帰ったものを使 っていた。これを“火計”と称した。火だけが时本産 で, あとはみな朝鮮渡来のものという意味である。

写真25 は純白に近く, 白薩摩の祖型をなすむのであ る。火計は南方型にはじまったもので, 形の上からはな 


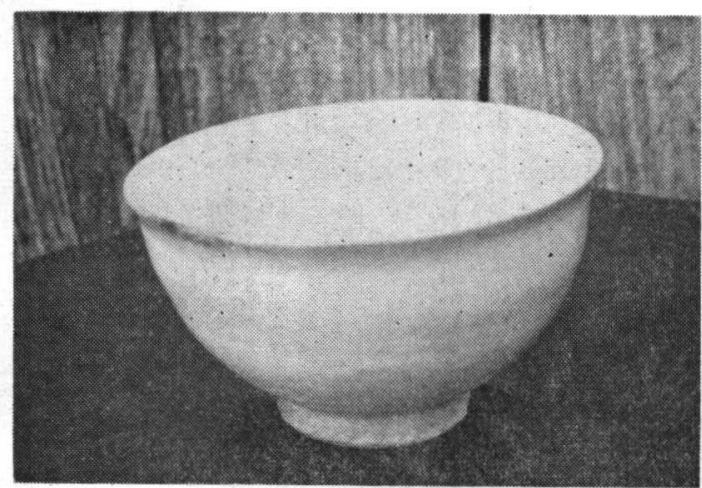

军真 25 火計茶碗 (その1)

白色火計茶碗, 慶長年間帖佐の宇都のかま

で，金海が焼いたもの。

口径 $14 \mathrm{~cm}$, 高さ $10 \mathrm{~cm}$

(鹿児島県加治木町罡曾木隆輝氏蔵)

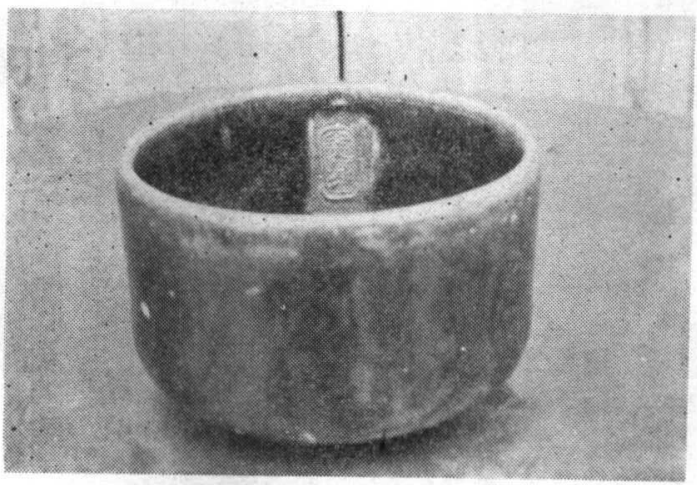

写真 26 火計茶碗 (その 2 )

黒色火計茶碗, 慶長年間帖佐の八日町のか

まで芳忠が焼いたもの。

口径 $10 \mathrm{~cm}$, 高さ $9 \mathrm{~cm}$

(鹿児島県加治木町 曾木隆輝氏蔵)

にかしら大陸的な感じを受ける。“火計”涂碗だけに 限られたものではなく，茶壸などにもみられる。

(b) 白薩 摩

島津藩では, 朝鮮渡来の白色陶土が減少すると, 苗代 川初代の庄屋, 朴平意に案内役をつけて, 領内各地を調 べさせ, 慶長19年 (1614) 藩内各地に陶土を発見した。 そして、これは揖宿郡山川村成川にあるるのが，特に良 質であることがわかった。吕た灰にして上薬に混ぜるナ ラの木む, 良質のものが, 東南方鹿籠村 (現在の枕崎 市)にあることがわかった。そこでそれらを原料とし て, 加治木の御里がまで試陶したところ, 純白の茶碗が できた。義弘公は名器の産地で名高い朝鮮の熊川のもの に, 非常によく似ていると称賛された。しかし, 鹿児島 および苗代川の自薩摩は民間の使用を許さず，すべて藩 用にのみ使われた。

もともと, 古い時代の薩摩焼きには模様などはなく, 白一色であった。それが慶安の初めのとろ (1648〜) か
ら，上絵付けがはじめられたという。写真27は白薩摩で ある。まえ中のものる, 両側のものる白の無地で, その 形からはまこそにふくよかな、大陸的な感じを受ける。 両側の二つは托鉢用の鉢によく似ているが，古い時代の 朝鮮には, 日常の食器のうちにこのような形のものがみ られるという。食器から変わったかどらかはわからない が，新しい時代の焼きには，この平茶碗のような形のも のはみられないようである。

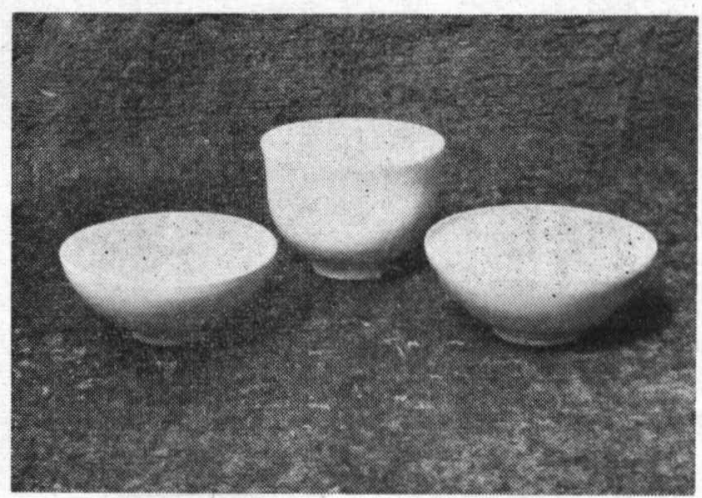

写真 27 白薩摩

高さは向加て左から $5.5 \mathrm{~cm}, 6.4 \mathrm{~cm}, 5.5 \mathrm{~cm}$ (鹿児帛市 美術馆陳列)

(c) 苗代川焼き

写真28 は義久公 (島津第16代) の御使用になったもの

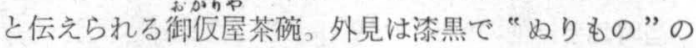
ように強い光沢がある。薩摩黒焼きの代表的なものとい われる。苗代川のかまからでた, 苗代川焼きとその道の 人は言う。

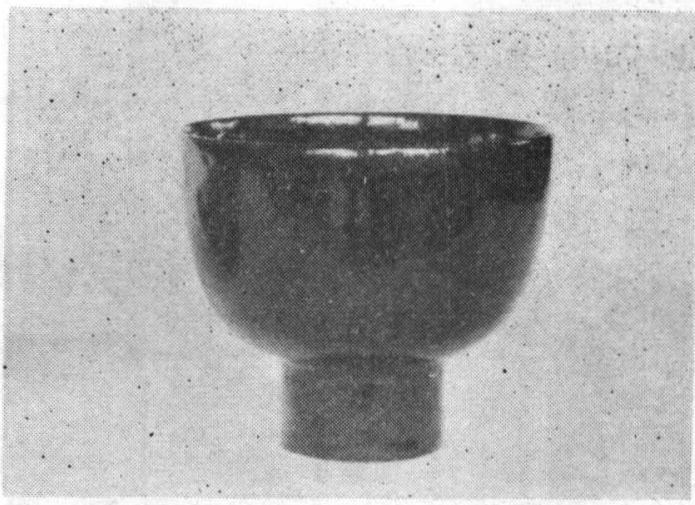

写真 28 苗代川焼き

御仮屋茶碗

（鹿児島市 中尾健次氏蔵）

(d) 堅野 焼き

義弘公が夢ぜられると，鹿児島館の家久公は，金海を 加治木から呼えで, 元和 6 年 (1620) 冷水町竪野にかま を開かせたが，翌年金海が死んだので，嫡子金和がその あとを継いだ。金和は家久公の命を受げて，前後 2 回肥 
後におむむき，鍋島藩の御用がま（有田）で研究し，青 磁, 染付白磁を会得して帚った。この堅野がまは島津藩 の御用がまとして，明治維新に至るまで連綿として続き 薩摩焼きの中枢をなした。军真29は竪野焼き茶碗, 向か って左は“紫べっ甲”，右は“なまこぐすり”。いずれ も堅野御用がまからでたものであるという。

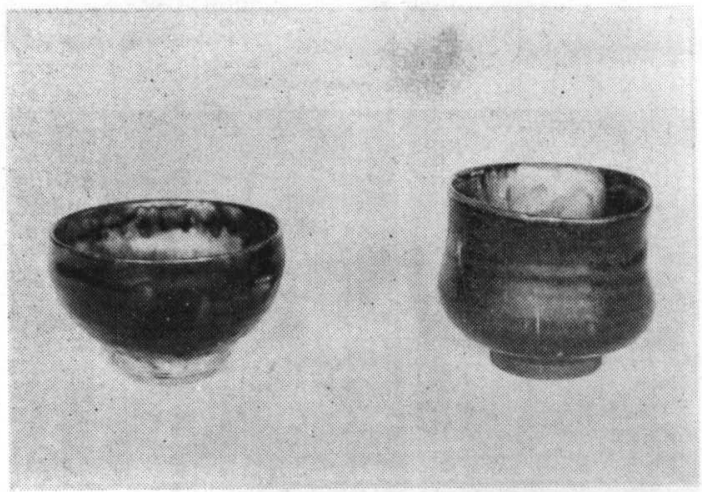

写真29 豎 野橴き

左は紫べっ甲，右はなまこぐすり

(鹿児島市 中尾健次氏蔵)

(e) 錦辛亲

白薩摩の雄とされる錦手は, 光久公の慶安年間 (1648 〜), 有村久兵衛という者が京都に留学して, 仁清から 伝授を受け，堅野で製作を始めたものである。

当時錦手は他のかまでは製作することを許されず，苗 代川でも製作を許されたのは，それから約 200 年後の天 保11年 (1840) であった。

写真30 の錦手茶碗は，打庭焼きの一つであるが，京都 五条の陶工で，代々錦光山と称し禁中の調度を製作した 青木宗兵衛の作と伝えられる。

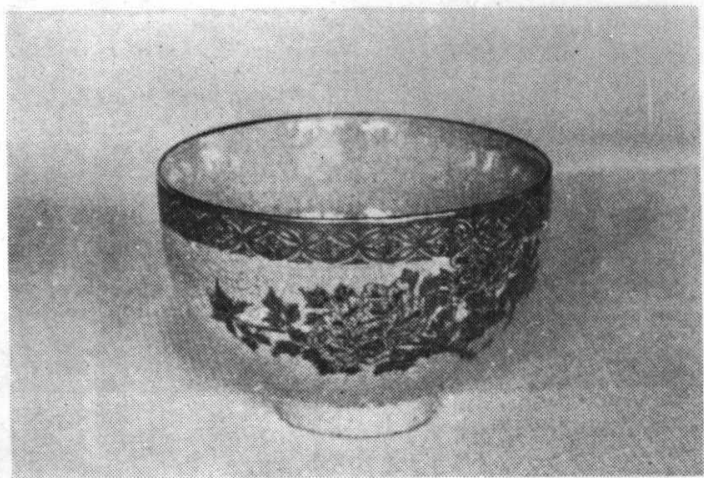

写真 30 錦 手茶 碗

錦 光山作

（鹿児島市 中尾健次氏蔵）

(f) 竜門司焼き

竜門司焼き (加治木) は, 鮮人山本碗右衛門が, 鹿児 島の㯺野で陶法定学び, のちいまの加治木小山田・茶碗
屋付近に良土を発見して, 元禄初年 (1688 ) 製陶を始 めたのが起こりで，その跡在当時小山田村・西別府・竹 子村三村の庄屋をつとめていた川原十左衛門が，聞弟と なって継いだ。十左衛門は芳工と称した。かれは肥前・ 筑前・筑後・京都・尾張・伊勢などに 歴遊して陶法を学 び，いわゆる鮫肌焼きなるるのを創始した。また竜門司 焼きは“黑もの”のほか，三彩の王流釉の技法を使 った“黑もの”も作り，陶器に明かるい色調を持たせ ている。いまの童門司焼きは，乙の子孫が続けて現在に 及えでいる民がまである。

写真 1 にみる 8 個の茶碗は, 元禄創業から幕末ころま での作といわれる竜門司焼きである。姿や色彩などに

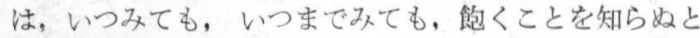
言われるほど，時代的渋味があり，同時にまた，近代的 清新ささえ感じられる。いずれも竜門司焼きの代表的の もの。竜門司焼きの流れをくむ指折りの陶工たちでさ え，今日との色彩を出そうとして，苦心を続けているほ どの逸品である。

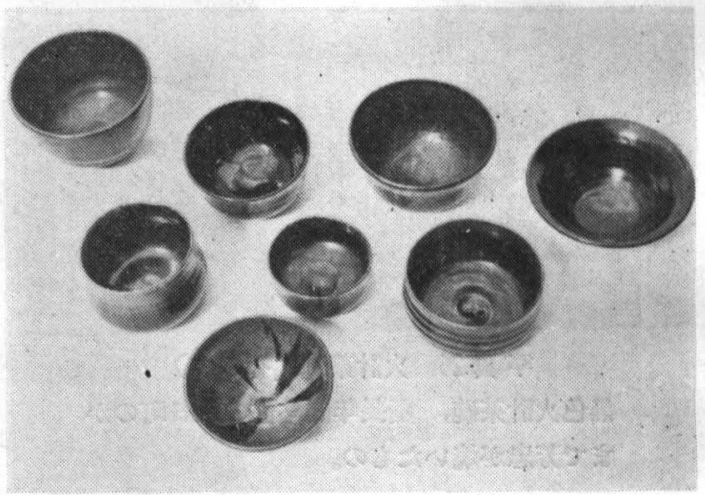

写真 31 竜門司焼き茶碗

(鹿児島市 美術館陳列)

(g) 帖 佐 焼き

帖佐のかまは，慶長13年 (1608) 義弘公が 加治木に移 管と同時に廃窝となったが，それから約60年後の宽文 5 年 (1665) に, 同町西餅田の験者小野光立が，民間の 力で開窯に成功し, 盛えに日用雑器を製造した。写真 32 , 33, 34 は古帖佐。

写真34 古帖佐焼き（その3）注, 帖佐烧きを再興した 小野元立院によって作り出された元立院焼き。との焼 きはどんこ焼き, 蛇蝎または松皮肌ともいう。“どん こ”は薩摩ことばで，俗にいう“ひきがえる”のこ と。はだがひきがえるに似ているところから，この名が 出たもの。しかし茶器の場合は“どえこ”とはいわな いで, 普通は“松皮肌”と呼ばれている。

\section{(h) 馬上 盃}

馬上で茶を飲むのにもちいられたところから，この名 が出たものだという。出陣のときには, 茶碗をくらにい 


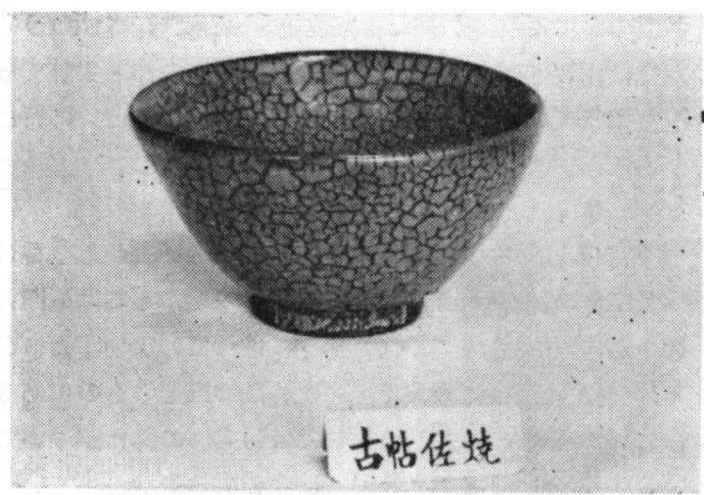

写真 32 古帖佐焼き (その 1 )

口径 $11.5 \mathrm{~cm}$, 高さ $9 \mathrm{~cm}$

（鹿児島市 美術館陳列）

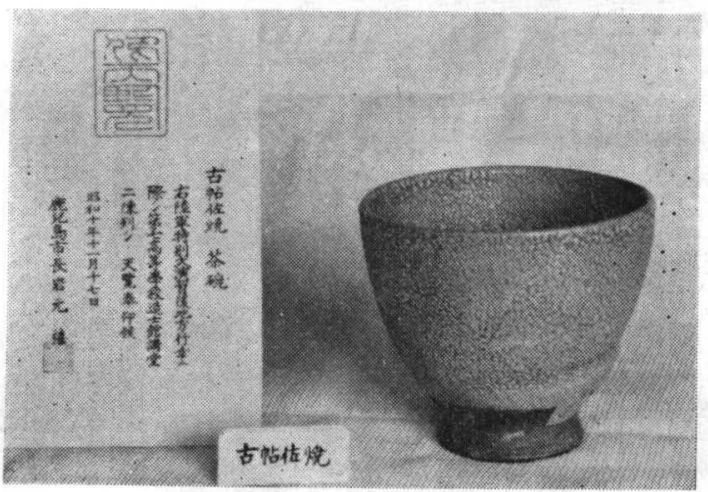

写真 33 古帖佐焼き (その 2 )

鮫肌焼き (大ざめ)

口径 $11.4 \mathrm{~cm}$, 高さ $10.3 \mathrm{~cm}$

（鹿児島市 美術館陳列）

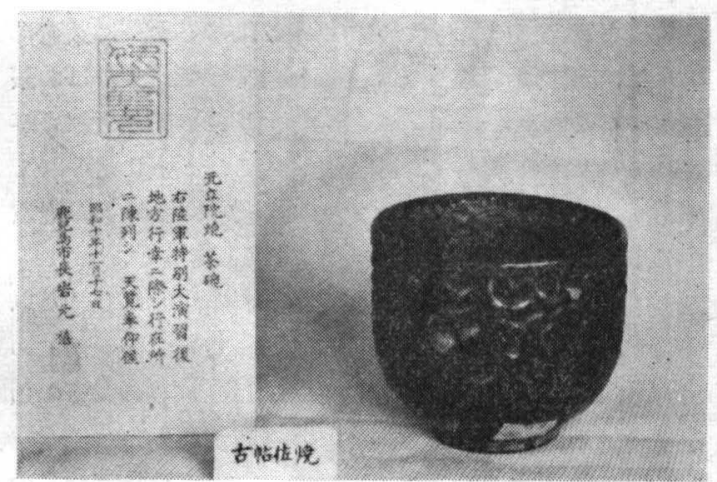

写真 34 古帖 佐 (その3)

元立院焼き茶碗 (松皮肌茶䛷)

口径 $10.9 \mathrm{~cm}$, 高さ $9.5 \mathrm{~cm}$

（鹿児島市 美術館陳列）

わえつけて出て行ったものといわれ，いとぞてにひもを 通す穴のあけてあるのもおむしろい。

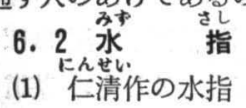

仁清は名を清兵衛といい, 山城の仁和寺で陶器を焼い

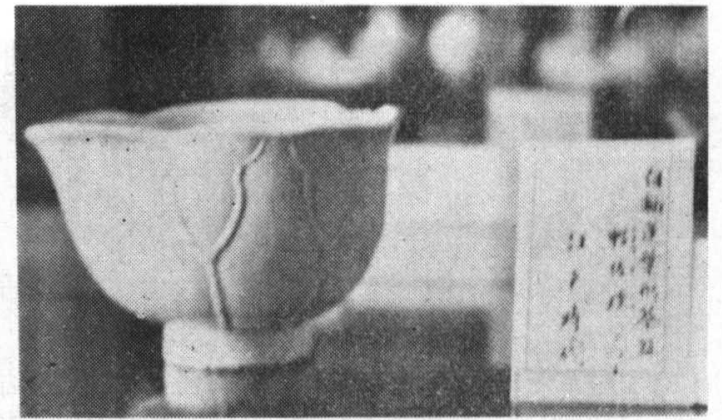

写真 35 帖 佐焼き

白釉蓮葉花形茶盌（江戸時代の作）

(東京博物馆陳列)
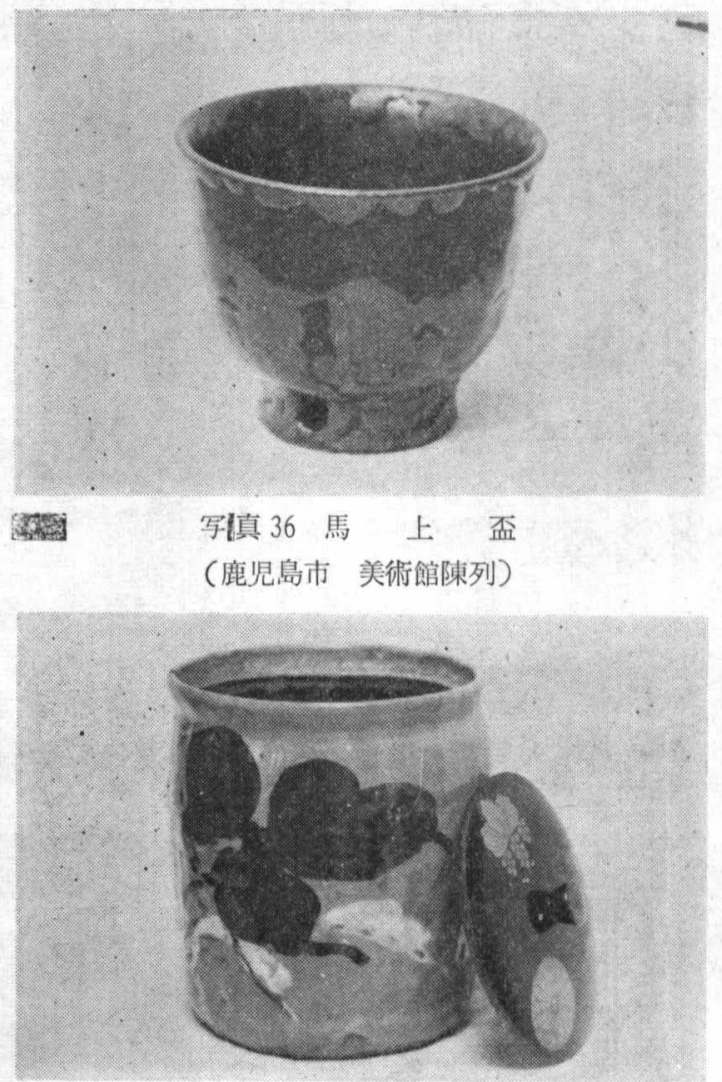

写真 37 仁清の水指 口径 $3.8 \mathrm{~cm}$, 高さ $13.6 \mathrm{~cm}$ (鹿児島市 尚古集成館陳列)

た。そのゆかりから仁清と名のった。仁清は錦絵にすぐ れたが，その作は今日わが国には，多く現存しないと言 われる。

写真 37 の水指は, うすい灰色の地に, “つたかずら” が墨絵で描かれている清素なものであるが，その姿とい い絵といい，寸分の陌がない。裏底に仁清の刻印が打っ てある。ふたは木製で黒の漆塗り, 菊ときりの絞章つき になっているが, おとらく高貴の使用になったものであ ろうと思われる。 


\section{（2）お庭焼きの大水指}

お莛焼きの大水指, 獅子に牨丹の図, 木村探元の絵付 け（鹿児島市, 山口宗恵氏蔵）（本誌 No. 8, p. 115 参 照)。

\section{3 茶构}

\section{(1) 斉彬公お手作りの茶杓}

斉彬公お手作りで，お茶道役村上寿庆の拝領した茶杓 が, 尚古集成館に保存されている(写真38)。

茶杓は 1 本で，これに竹筒の容器がついている。竹筒 には仙玈竹と書かれてあるだけで，まことに素朴なもの であるが，このなんのかざり気のないところに，かえつ て茶道の本義が存するかのように思えるし，またこれを お手作りされたことによって，斉涁公のお人柄の一端が うかがえるかのようにも感じられる

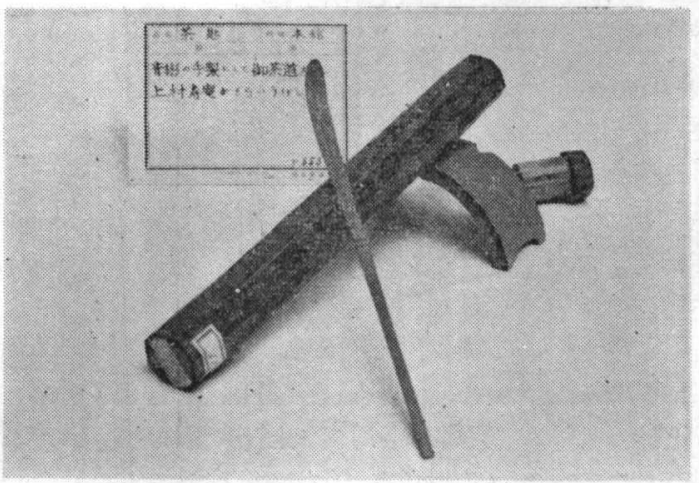

写真 38 槂公お手作りの茶杓

茶杓の長さ 約 $2.1 \mathrm{~cm}$ (鹿児島市 尚古集成館陳列)

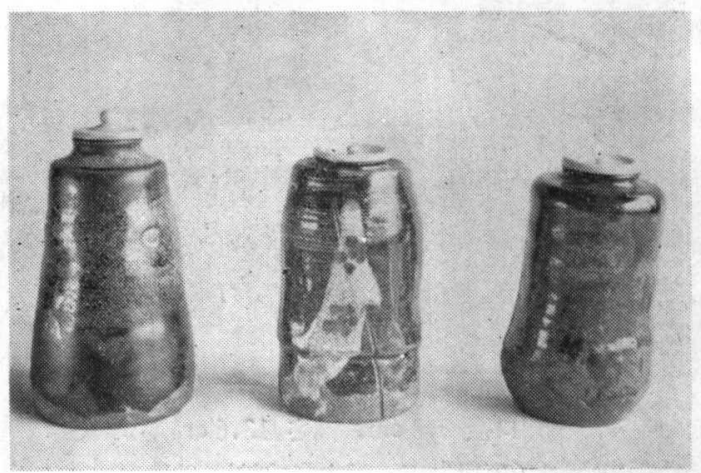

写真 39 茶入れ (その 1) 古帖佐焼き茶入れ 向って左中左

$\begin{array}{ccccc}\text { 口 } & \text { 徍 } & 1.0 \mathrm{~cm} & 1.3 \mathrm{~cm} & 1.3 \mathrm{~cm} \\ \text { 直 径 } & 4.5 \mathrm{~cm} & 5.4 \mathrm{~cm} & 5.4 \mathrm{~cm} \\ \text { 高 さ } & 10.5 \mathrm{~cm} & 10.0 \mathrm{~cm} & 10.5 \mathrm{~cm} \\ & \text { (鹿児島県加治木町 } & \text { 新納教義氏蔵) }\end{array}$

\section{4 茶入 れ}

(1) 茶入れ (その 1) 古帖佐焼茶入れ

写真39 は加治木町於里 (鹿児島県) にかまを設け, 義
弘公の命により焼うれた古帖佐焼き茶入れ，3 個のうち 左端は作者不明, 中は芳仲, 右端は金海の作, 素朴で豪 快な薩摩人の気風によく合っており，渋い色合いに特色 があるという。

\section{（2）茶入れ（その 2)}

写真40 はいろいろの形の茶入れである。右から 2 番目 は芳工作の銘がはいっているが，その他のものは竜門司 焼きか，古帖佐焼きか明らかにされていない。ともか く，茶人には目に入れてもいたくないほどのものである らしい。いちばん左端のものには, 木製のふたがついて いる。色合いは黒かっ色で, 渋味のある無地, 小さい割 合いに重く,すわりもよい。

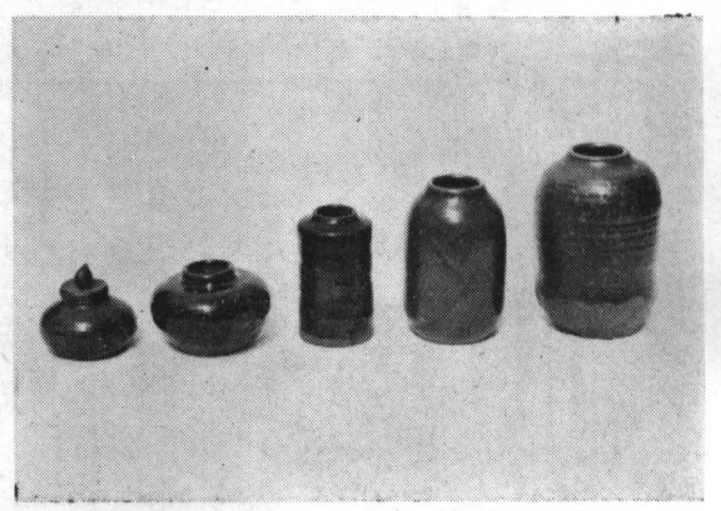

写真 40 茶入れ (その 2 )

高さ左加ら $3.3 \mathrm{~cm}, 4.5 \mathrm{~cm}, 6.7 \mathrm{~cm}, 8.2 \mathrm{~cm}$ $10.3 \mathrm{~cm}$

（鹿児島市 美術館陳列）

\section{5 茶 壶 の 類}

茶壳といえば徳川時代，将軍家に納めるお茶は茶壸に 入れて, 京都から江戸まで運ばれたもので, それはお茶 螜道中とよばればれ，大名行列と同じに，丁重な扱いが されてきたものである。子守歌にある「茶壶に追われて トッピンシャン……とらのは, そのころのお茶壶道 中の威勢を伝える名ごりということもできよう。

ともかく，茶の貯蔵に金物が使われるようになった以 前はもちろん，その後も金物沙常に貴重であったため に, 少なくとも明治の末期ころまでは, 焼物の茶壶の類 が広く実用に供せられてきたもののようである。

しかし、すき者の間にもちいられた茶壸は格別なもの で, ことに “口切り茶の湯”などという茶の湯の儀式 には, 諸大名のみえも手伝って, 飛び切りぜいを尽した 壶が求められたらしく，それにはめっぽう金をかけてき たもののようである。

茶畐に関する記録はあまり多くはないが, 日本茶業史 に次のような一節がでている。それによると『茶を蔵し て香気を保たしめんと欲せば，先ず茶壶の良否を撰ばざ るべからず。茶壶は呂宋の産を以て最とせるも, 茶道の 興隆に従って遂にその欠乏を告ぐるに至り，秀吉乃ち堺 
の人納屋助左衛門をして, 呂宋に茶壸五十個を購わし め, 利休に命じてその良否を判ぜしめ, 之を諸公に分興 す9)』となっている。

ついでに久生十蘭（先年物故された。）が, “呂宋 の嗀”をオール読物に書いている。これは小説であっ

て, 内容についてはもちろん真偽のほどは知る由もない が, 戦国の世の茶监というものに, どのようにぜいを尽 されたかがうかがえて興味深いものがある。

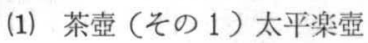

この监は義弘公当時の州化人 (朝鮮人) 金海が, 大隅 国帖佐 (佮良郡) で焼いた大型茶壶 (古帖佐)で, 薩摩 焼きの初か゚ま品である。原料陶土は朝鮮から輸入した火

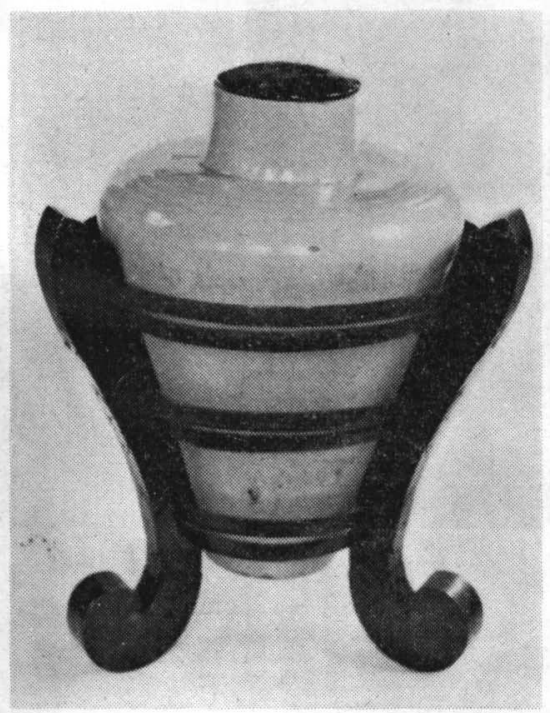

写真 41 茶煏 (その1) 太平楽喆 (鹿児島市 尚古集成館陳列)

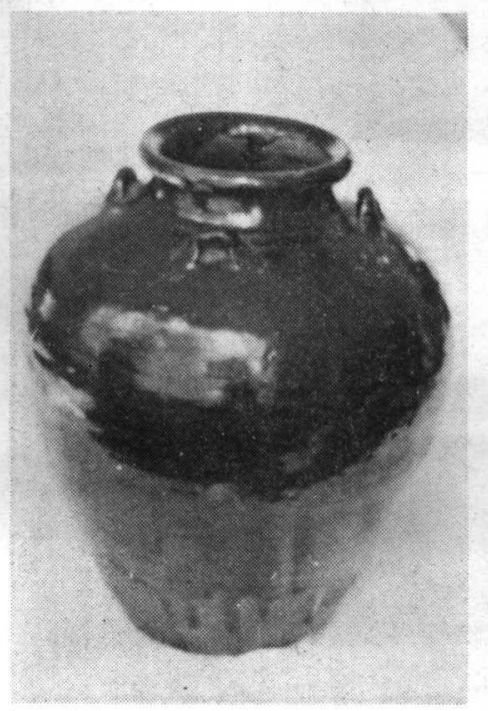

写真 42 茶壶 (その 2 ) 帖佐焼き茶壶 (古帖佐) 高さ $32.5 \mathrm{~cm}$ (鹿児島市 上野幸枝氏蔵)
計と伝えられている。（尚古集成館説明書による。）

(2) 茶锅 (その2) 帖佐焼茶暈

つくりは薄手ではなはだ軽く，まことに上品な姿をし ている。色は漆黑で強い光沢をもっている。古帖佐とい われる。

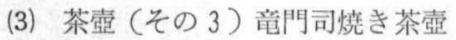

腰高の壷, 肩の張りからすそのしぼり具合, ふくよか でかざり気のないこの姿からは，まことに清素な感じを うける。竜門司二代の陶工, 芳工作の銘入りできわめて 貴重なものである。

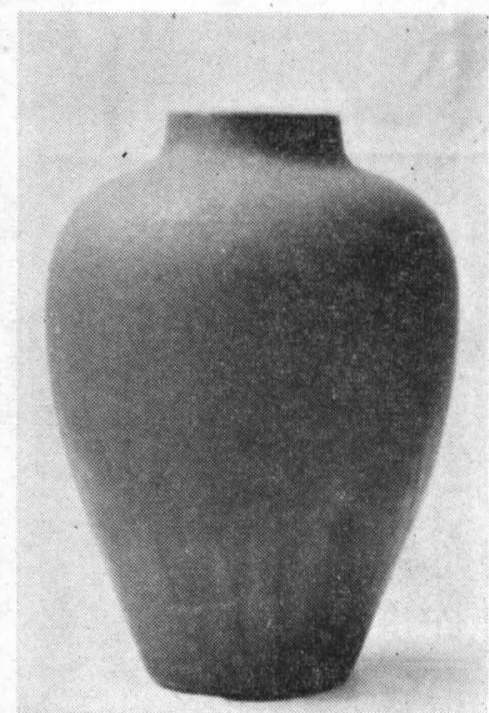

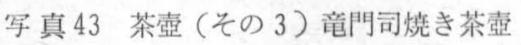
竜門司焼き, 鮫肌 (芳工作)

口径 $14 \mathrm{~cm}$, 䏱径 $34 \mathrm{~cm}$ (鹿児帛市 美術館陳列)

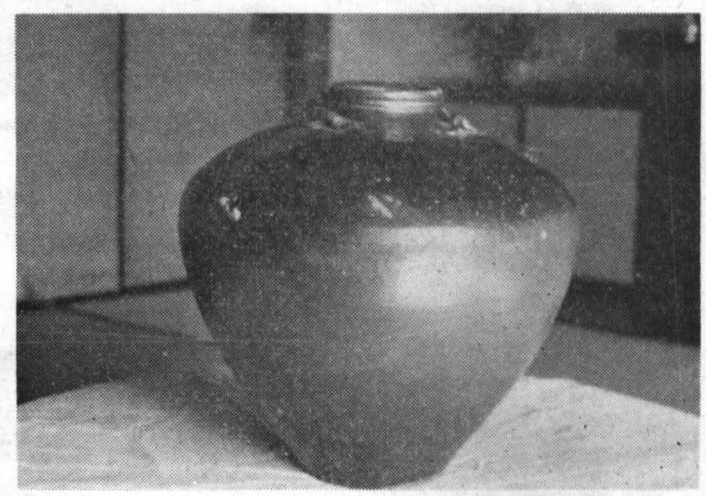
写真 44 茶 鞓 (その 4$)$
高さ $35.3 \mathrm{~cm}$
(鹿児岛市 中村勝太郎氏蔵)

(4) 茶 蒏 (その 4$)$

䥻のつくりは薄手ではなはだ軽い。へラで仕上ゲたよ うな跡がみえる。耳は四つ。耳には鉛筆の通るくらいの 穴があけてある。色は黒かっ色で肩のところまで上薬が 
つよい。はだ色がみごと迟のの印がはいっている。いん ベ焼きではなからうかと言われる。

\section{(5) 茶 壸 (その 5)}

壹のつくりは薄手ではなはだ軽い。ロクロをもちいた 形跡はなく， へラで仕上げた跡と，刷毛目の跡が明らか である。肩の張りは大きく腰は思い切りほそくしぼって あり，ようやく立っているほどである。胴の上半分は濃 い青らん色の上薬がつよい。上薬は嗀の内側にまでかか っている。この寑は串木野市の旧家奥田家から譲り受け たもので, ルソン盇と伝えられる。

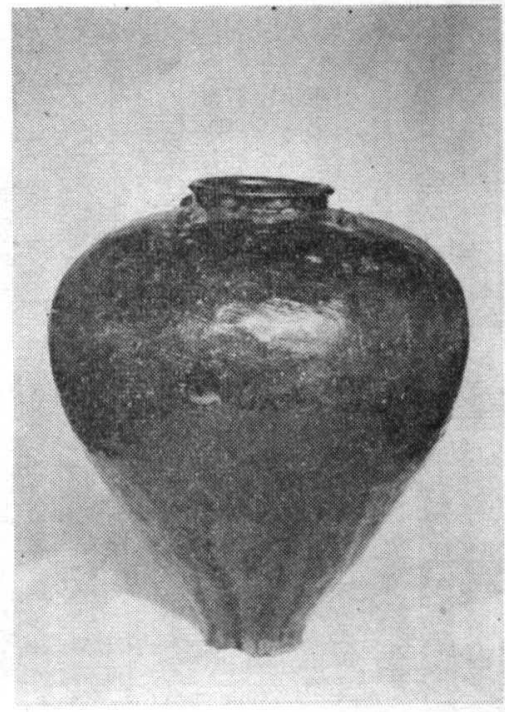

写真 45 茶 壶 (その 5 )

高さ $59.1 \mathrm{~cm}$

（鹿児島県伊集院町 伊藤政信氏蔵）

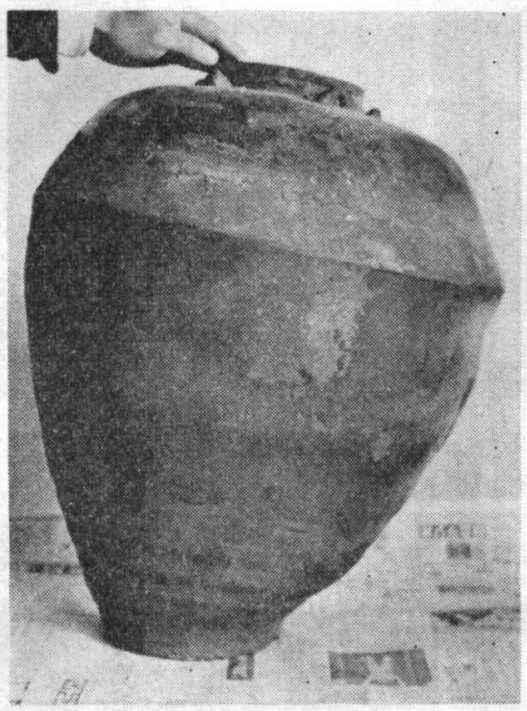

写真 46 茶 壸 (その6)

高さ $49.1 \mathrm{~cm}$

（鹿児島県谷山市 川上矢吉氏蔵）
(6) 茶监（その6)

つくりは薄手で軽い。形はややいびつにできていて, 手離しでは立たない。耳は四つ。色は緑黄かっ色, 胴の 上半は上薬がつよくかかっている。斜めからみるとにじ 色に光る。深味のある色合い。父の代までは茶壸として もちいられていたという。

\section{(7) 茶壶 (その7)}

つくりは薄手ではなはだ軽い。耳は四つ。姿がまこと に上品で落ち付きがある。地色は茶かっ色, 肩から上は 上薬が強くかけられ，べつ甲色かなり古いものらし く, ところどころ上薬のはげ落らたあとが見える。

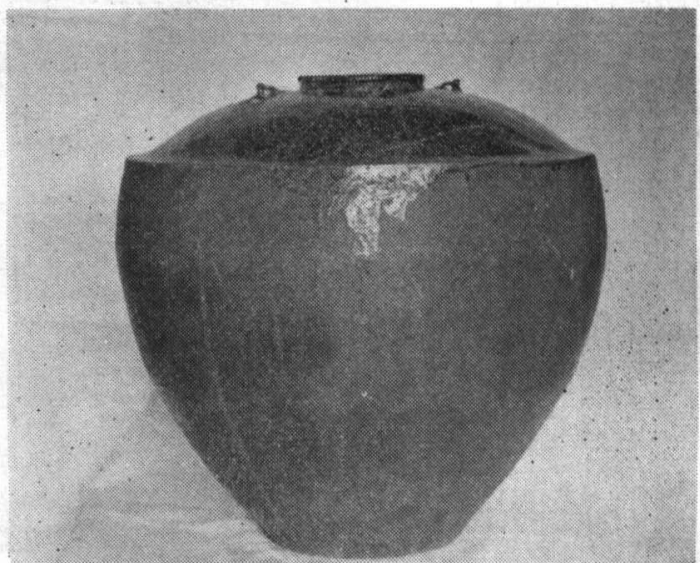

写真 47 茶 壶 (その 7 )

高さ $45.2 \mathrm{~cm}$

（鹿児島県伊集院町 梅之家蔵）

(8) 茶惡 (その 8)

大型茶壬冖゙ある。色は灰かっ色,耳四つ。山之内才 次氏の父は鹿照島の伊集院家に仕えた人， その関係で， 当時鹿児島から 持ち帰ったものではなからうか上言われ ている。姿やロら゙くりなどからして“ナンパン焼き”で はなからうかと言われている。

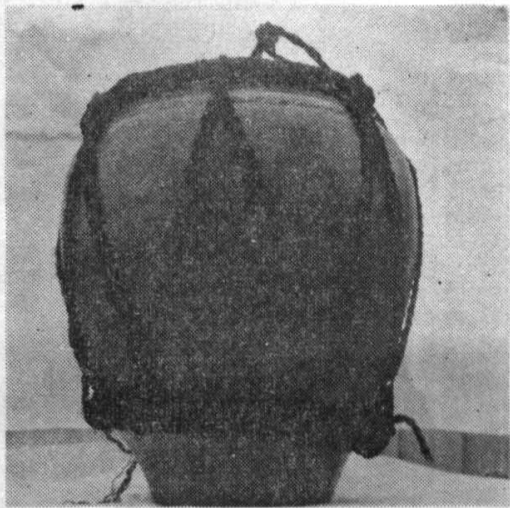

写真 48 茶 壸 (との 8 ) 高さ $73.9 \mathrm{~cm}$

（鹿児島県川内市 山之内才次氏蔵） 
(9) 小出し茶壹

(a) 小出し茶壱 (竜門司焼き)

写真49 の三つとも, 竜門司焼き小出し茶瞉, ふくよか な肩の張り，なえともい充い趣のある姿をしている。 中央と右の 2 個には，芳平の銘各はいっている。
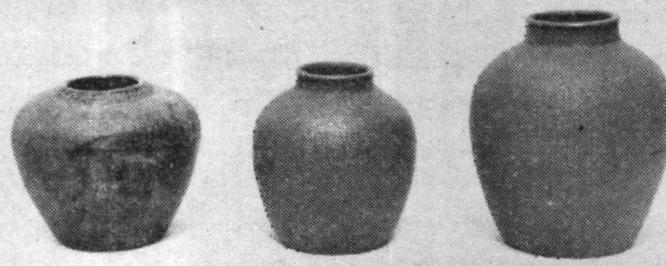

写真 49 小出し茶壷 (竜門司燒き) 高さ左から $9 \mathrm{~cm}, 11.5 \mathrm{~cm}, 13.9 \mathrm{~cm}$

（鹿児島市 美術館陳列）

\section{(b) から゙せら゙た小出し茶壶}

かぶせぶたの茶盇ははなはだ珍しいという。ふたの形 からすると，時代は心なり古いらしく，あるいは苗代川 以前の，串木野㜔きではなからうかとも言われる。はだ 色は竜門司燒きに似ているところが，むしろ苗代川焼き に近いという(写真50参照)。

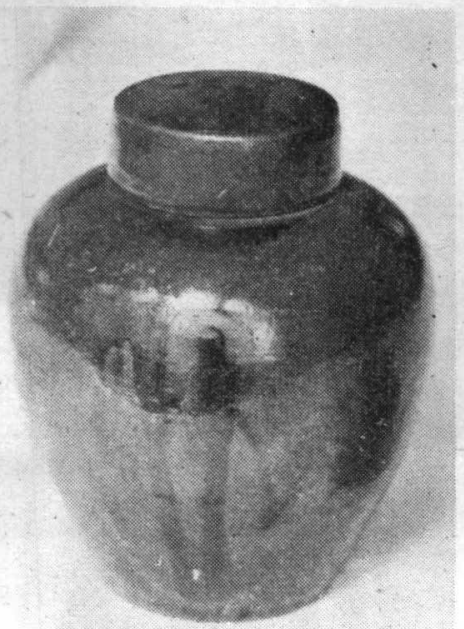

写真 50 かぶせぶた小出し茶㹃 高さ $17.5 \mathrm{~cm}$ （鹿児島方 美術館陳列）

\section{(c) のせぶた小出し茶壼}

なに焼きかわからないが，時代ものであることには間 違いないと言う。のせぶたの茶壼は，から゙せぶた茶壳と

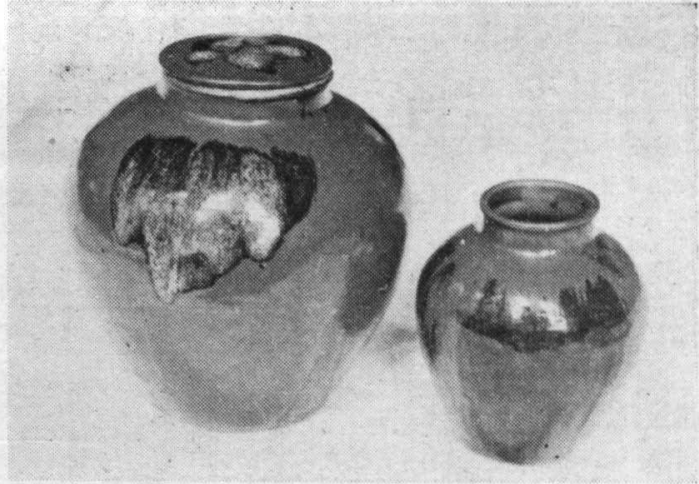

写真51 のせぶた小出し茶钲

ともにはなはな゙珍しい壱とせられている(写真51参照)。

\section{6 おわりに}

茶に関して古くから薩摩に法わる物件には茶碗，茶壸 をはじめ，さまざまの茶器の類があげられる。ここに揭 げたものは，いずれも島津藩政時代の作であり，しかも 家宝として，あるいは重要な文化財として，その一つ一 つが，掛け替えのない代表的な品ばかりである。紙面の 都合で，今回は紹介できなかった資料も，まだ手許にか なり残されている。これらのほかに, わたくしの知らな い品も，お括らく数多く各地に保存されていることであ ろう。

これら茶器の類が，島津藩政時代の茶の歴史と，どの ような関係におかれてきたかは，即断をしかねるところ であるが，それにしても，これらの物件からして歴代藻 主が茶事にきわめて関心が深かったということはうかが うことができる。

ともかく，とのように茶に関係する交化的遺産が，い つの間にか，しらずしらずのうちに，逸散することのな いようにしたいものである。

今次太平洋戦争による戦災は，交化財の多くを灰じえ に帰したことであろう。阿久根の小木原三楽は交政の 昔, 藻主斉宣公のちょう爱をうけ, かつ, 茶業に尽くし た功績により，藩公から茶器その他をしばしば拝領せら れた由が串実に残っているが，戦災をこおむり，今はそ の何物も残されていないという。まことに惜しいととで ある。これらはほんの一例にすぎないのである。

このようなことからして, 名器は名器として, たいせ つに保存すべきは申寸までも走いが，历が一ということ をも考えるならば，なんらかの形で記録として後世に残 しておくこ々も，あながちむだとは思われない。

この調査に当たって，貴重な資料を快く御提示下され た多くの方々に詨しては，心から厚くお礼を申上げた い。な扮島津家加は資料の公表に対して，格別の便宜 をいただいた。中尾健次氏および沈寿官氏御夫妻から は，資料の提示とともに，多くの助言をいただいた。鹿 


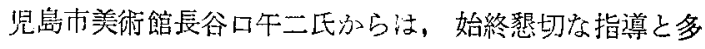
大の助言をいただいた。仮屋園健次氏は家業のかたお ら，㓌料の収集に奔走して下さった。これらの諸氏に対 しては，深く感謝の意害亦るしだいである。

\section{7 参 考 文 献}

61）日置郡茶業組合：日置郡茶鄴誌, p. 32～35(1939).

62）鹿罗島県社会科研究会亭等学校歴史部会：鹿児島 の歴史, p. 75 76 (1959).

63）加治木古老物話（写本），51枚目の裹.

－64）鹿児島罧社会科研究念颜等学校歴史部会：鹿児島
の歴史 p. 76〜77 (1959).

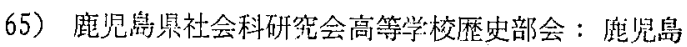
の歴史 p. 77 (1959).

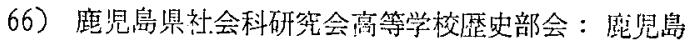
の歴史 p. 65 (1959).

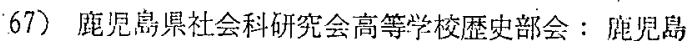
の歴史 p. 76 (1959).

68）照国神社社務所：物件を通じて見たる斉樹公， p. 42 (1933).

69）茶業組合中央会議所：日本茶媄里，p. 526 (1915)。

70）文芸春秋新社：オール読物，p. 145１64（1957）。

(Apr. 28, 1961) 